\title{
DAYA HAMBAT EKSTRAK BAWANG PUTIH TERHADAP S.aureus dan TOTAL MIKROBA DALAM DAGING
}

\author{
Dede Zainal Arief, Nana Sutisna Achyadi, Risma Franisa \\ Program Studi Teknologi Pangan, Fakultas Teknik, Universitas Pasundan, J1. Dr.Setiabudi No 93, Bandung, 40153, \\ Indonesia \\ E-mail : dedezainalarief17@unpas.ac.id
}

Diterima pertama kali: 12 Januari 2020, Direvisi: 13 Januari 2020, Disetujui untuk publikasi: 16 Januari 2020

\begin{abstract}
The research objective is to determine the inhibitory garlic extract at different concentrations to inhibit the growth of Staphylococcus aureus and lowers total microbes in beef based on the rate of microbial growth. The study consisted of four stages: stage one study aims to examine the components contained in extracts of garlic with GC-MS. Phase two study aims to determine the time of maceration of garlic extract the most good, knowing how long the antimicrobial compounds found in garlic extract can survive, as well as to determine the relationship when maceration on the number of colonies of microbes and microbial growth rate. Three phase study aims to determine the concentration of garlic extract is most effective. Research stage four which applications use garlic extract concentration and soaking time chosen which can inhibit the growth of microbes on beef during storage Based on the results of this study concluded that the total microbes and bacteria Staphylococcus aureus contained in beef can be inhibited by garlic extract views from the rate of microbial growth.
\end{abstract}

Keywords: Garlic extract, Inhibitor, microbes

\section{Pendahuluan}

Tanaman bawang putih termasuk tanaman yang sangat menguntungkan di dalam pengolahan, baik dijadikan sebagai bumbu masakan maupun obat-obatan. Permintaan akan tanaman bawang putih sangat tinggi dan menempati urutan kedua setelah bawang bombai di dunia. Khusus di dalam negeri produksi bawang putih semakin meningkat seiring dengan penanganan pra panen dan pasca panen yang baik dan efisien yang dapat mengurangi kerugian dari hasil tersebut. Menurut kementrian pertanian Republik Indonesia, luas panen bawang putih di Indonesia pada tahun 2013 adalah 2.479 Ha. Produksi bawang putih pada tahun 2013 adalah 15.766 ton dan produktivitas bawang putih tahun 2013 adalah 10,22 ton/Ha (Kementrian Pertanian RI, 2013).

Pada umumnya pemanfaatan bawang putih digunakan sebagai bumbu masak seperti digunakan dalam pengolahan daging sapi. Selain digunakan sebagai bumbu masak, bawang putih juga memiliki beberapa manfaat sebagai antibakteri, antijamur, antivirus dan antiprotozoa.

Bawang putih memiliki kandungan kimia seperti karbohidrat, protein, lemak, vitamin, mineral, sterol, saponin, alkaloid,flavonoid, dan triterpenoid. Aktivitas antimikroba bawang putih berasal dari senyawa organosulfur. Salah satu senyawa organosulfur yang bertindak sebagai antibakteri yaitu allicin. Allicin mampu menghambat pertumbuhan bakteri gram positif maupun gram negatif (Safithri, 2004).

Daging sapi merupakan salah satu bahan pangan yang memiliki nilai gizi tinggi, terutama protein. Nilai gizi yang tinggi mengakibatkan bahan pangan ini disukai konsumen untuk memenuhi kebutuhan gizi sehari-hari, sehingga setiap hari daging sapi diproduksi dalam jumlah yang banyak. Pada saat ini, kebutuhan masyarakat Indonesia akan bahan pangan ini terus mengalami peningkatan dari tahun ke tahun. Hal ini disebabkan oleh semakin pesatnya pertambahan jumlah penduduk dan semakin banyaknya masyarakat yang sadar akan pentingnya mengkonsumsi bahan pangan yang bernilai gizi tinggi. Namun peningkatan konsumsi daging tersebut diikuti pula oleh kesadaran masyarakat untuk mendapatkan daging dengan mutu yang baik diantaranya memiliki penampakan, warna, aroma, rasa bahkan kandungan protein yang tinggi.

Daging sapi termasuk salah satu bahan pangan yang sangat rentan terhadap kontaminasi mikroorganisme karena kandungan nutrisinya yang cukup tinggi dapat menjadi sumber makanan bagi mikroorganisme. Daging mengandung nutrisi berupa air, protein, lemak, mineral dan sedikit karbohidrat. Kandungan air yang tinggi dalam daging sapi, juga menjadikan bahan pangan ini sebagai salah satu media yang sangat ideal bagi pertumbuhan dan perkembangan mikroorganisme. Daging sapi yang sudah terkontaminasi oleh mikroorganisme akan mengalami kerusakan dan penurunan daya simpan, sehingga menurunkan kualitas dari pada bahan pangan tersebut.

Salah satu cara untuk mempertahankan kualitas dan daya simpan pada daging sapi dapat dilakukan dengan memberikan perlakuan pada daging sapi tersebut. Perlakuan yang biasa dilakukan adalah dengan penambahan bahan pengawet. Umumnya pada saat ini bahan pengawet yang banyak digunakan adalah bahan pengawet sintetis, sehingga kurang baik untuk 
kesehatan konsumen. Oleh karena itu, bahan pengawet alami bisa menjadi alternatif terbaik yang dapat digunakan untuk mempertahankan kualitas dan memperpanjang daya simpan daging sapi serta tidak membahayakan kesehatan konsumen. Salah satu bahan pengawet alami tersebut adalah dengan menggunakan bawang putih (Bayu, 2011).

\section{Bahan dan Metode Penelitian}

Bahan baku utama yang digunakan adalah bawang putih varietas lumbu hijau. Media uji yang digunakan untuk mengetahui aktivitas zat antimikroba yang terdapat pada ekstrak bawang putih adalah sapi lokal.

Bahan yang digunakan untuk analisa adalah aquadest, etanol, Nurtien Agar dan Manitol Salt Agar.

Alat yang digunakan dalam ekstraksi adalah timbangan, pisau, blender, jar, kertas saring whatman 40, water jet, gelas kimia.

Alat yang digunakan untuk analisis adalah cawan porselen, timbangan digital, oven, desikator, tangkrus, penetrometer, $\mathrm{pH}$ meter, gelas ukur, gelas kimia, batang pengaduk, pipet volumetrik, tabung reaksi, filler, cawan petri, inkubator , Autoclave, jarum ose, kapas, kasa, spatula, erlenmeyer, GC-MS.

Penelitian yang dilakukan dibagi menjadi 4 tahap sebagai berikut.

Tahap I : Memeriksa komponen yang terdapat dalam ekstrak bawang putih dengan menggunakan kromatografi gas GC-MS.

Tahap II : Menentukan waktu maserasi ekstrak bawang putih yang paling baik, mengetahui berapa lama senyawa antimikroba yang terdapat dalam ekstrak bawang putih dapat bertahan, serta untuk mengetahui hubungan waktu maserasi terhadap jumlah koloni mikroba dan laju pertumbuhan mikroba. Pemilihan waktu maserasi yang paling baik dapat dilakukan dengan cara melihat laju pertumbuhan Staphylococcus aureus dan total mikroba yang paling rendah.

Tahap III : Menentukan konsentrasi ekstrak bawang putih yang paling efektif dalam menghambat Staphylococcus aureus dan total mikroba, serta untuk mengetahui hubungan konsentrasi ekstrak bawang putih terhadap jumlah koloni mikroba. Pemilihan konsentasi yang paling efektif dapat dilakukan dengan cara melihat pertumbuhan Staphylococcus aureus dan total mikroba yang paling rendah.

Tahap IV : Penggunaan konsentrasi ekstrak bawang putih dan lama perendaman terpilih yang dapat menghambat pertumbuhan mikroba pada daging sapi selama penyimpanan.

Rancangan percobaan yang digunakan adalah regresi linier sederhana dengan metode percobaan

$$
\mathrm{Y}=\mathrm{a}+\mathrm{bX}
$$

\section{Hasil dan Pembahasan \\ Tahap I}

Berdasarkan data kromatogram yang diperoleh dari analisis bahwa komponen-komponen senyawa organosulfur yang terkandung dalam ekstrak bawang putih diantaranya adalah trisulfide di-2-propenyl dengan waktu retensi sebesar 9,300 menit, luas area 17,21\%, Disulfide di-2-propenyl dengan waktu retensi 7,010, luas area 5,43. Trisulfide, methyl 2 propenyl dengan waktu retensi sebesar 7,680 menit, luas area $3.55 \%$. Tetrasulfida,di 2 propenyl dengan waktu retensi sebesar 7,235 menit, luas area 3,11\%. Diallyl disulphide dengan waktu retensi 7,174 menit, luas area $1,73 \%$. Diallyl disulfide dengan waktu retensi 11,415 menit, luas daerah 0,45\%. Trisulfide, dimethyl (CAS) 2,3,4Trithiapentan dengan waktu retensi sebesar 5,802 menit, luas area $0,28 \%$.

Ada banyak komponen sulfida yang terdapat dalam bawang putih seperti allicin, diallil trisulfida, metil allil trisulfida, allil sulfida, diallil tetrasulfida tetapi, dalam pengujian GC-MS yang telah dilakukan tidak terdeteksi.

Hal itu dapat disebabkan oleh beberapa faktor yaitu suhu penyimpanan, pelarut yang digunakan, jeda waktu selama pengujian dan penghancuran bawang putih yang tidak sempurna.

Suhu penyimpanan yang tidak stabil mengakibatkan komponen-komponen sulfida terdegradasi menjadi komponen lain. Pelarut yang digunakan sudah mengalami penguapan sehingga tidak dapat mengikat kuat komponen-komponen sulfida. Adanya jeda waktu pada saat akan dilakukan pengujian menyebabkan senyawa organosulfur rusak sebelum diidentifikasi. Penghancuran bawang putih yang kurang halus sehingga menyebabkan komponen-komponen sulfida tidak muncul dan penyerapan komponen sulfida oleh pelarut kurang optimum.

Allicin bersifat tidak stabil dan allicin hanya bertahan sebentar untuk selanjutnya mulai terdegradasi. (Katria, 2006).

Berdasarkan hasil analisis ekstrak bawang putih dengan menggunakan GC-MS didapatkan senyawa diallyl disulfide dengan waktu retensi 7,174 menit, luas area $1,73 \%$ dan tinggi area $2,54 \%$. Senyawa diallyl disulfide berfungsi sebagai antimikroba selain itu, senyawa ini dapat menghambat bakteri gram positif dan gram negatif.

\section{Tahap II}

Hasil penelitian tahap II dapat dilihat pada grafik jumlah koloni dan laju pertumbuhan dibawah ini 


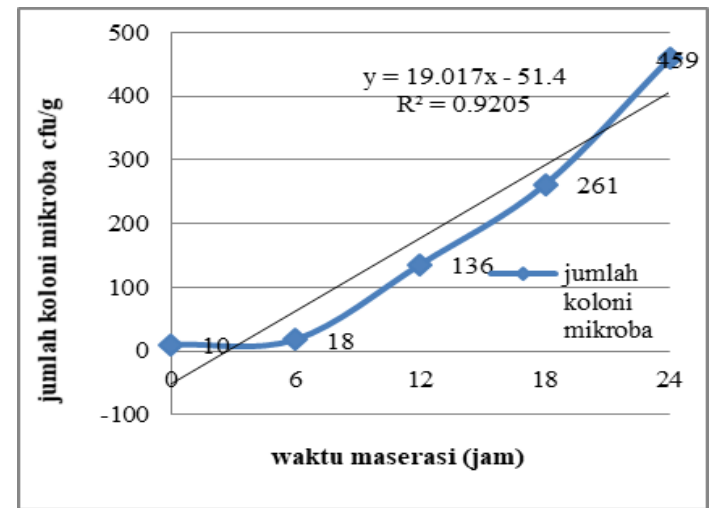

Gambar 1. Grafik total koloni mikroba yang tumbuh selama masa inkubasi 24 jam setelah dihambat oleh ekstrak bawang putih yang dibuat dalam waktu maserasi yang berbeda-beda.

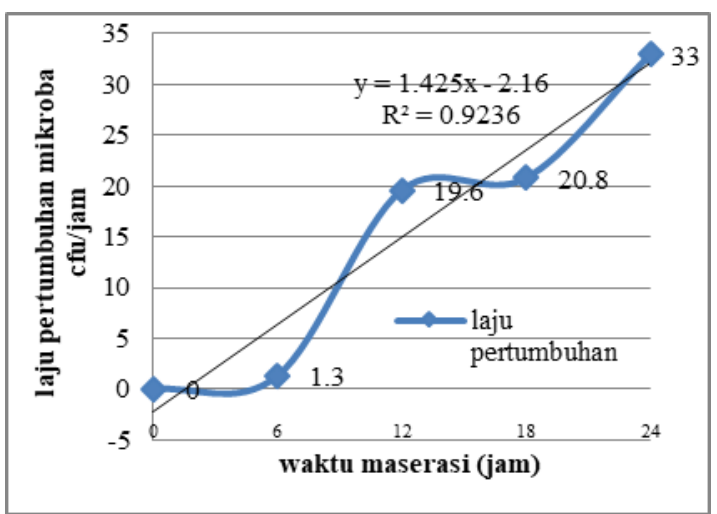

Gambar 2. Grafik jumlah koloni Staphylococcus aureus yang tumbuh selama masa inkubasi 24 jam setelah dihambat oleh ekstrak bawang putih yang dibuat dalam waktu maserasi yang berbeda-beda

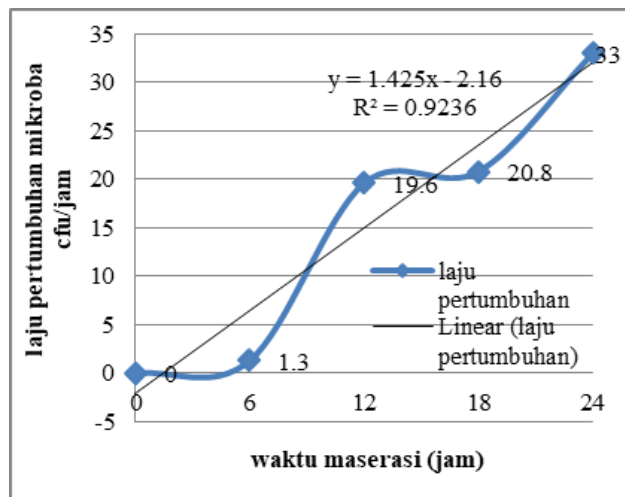

Gambar 3. Grafik laju pertumbuhan total mikroba yang tumbuh selama masa inkubasi 24 jam setelah dihambat oleh ekstrak bawang putih yang dibuat dalam waktu maserasi yang berbeda-beda

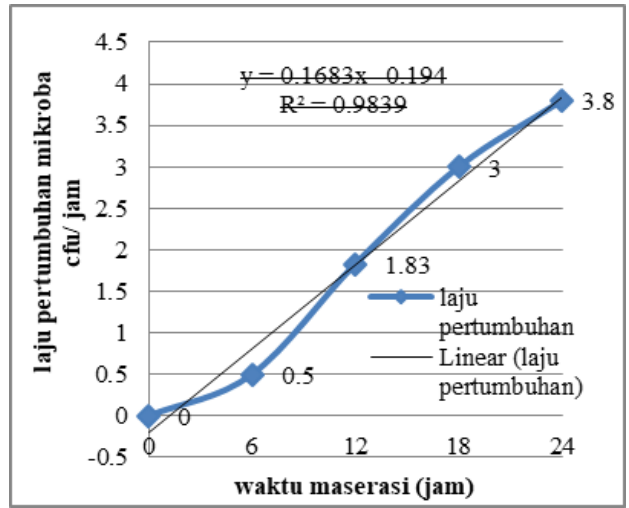

Gambar 4. Grafik laju pertumbuhan Staphylococcus aureus yang tumbuh selama masa inkubasi 24 jam setelah dihambat oleh ekstrak bawang putih yang dibuat dalam waktu maserasi yang berbeda-beda.

Berdasarkan grafik diatas didapatkan kurva linier dari total koloni mikroba dengan persamaan $\mathrm{Y}=$ 19,017x-51,4 dan $\mathrm{R} 2=0,9205$ sedangkan pada jumlah koloni Staphylococcus aureus didapatkan kurva linier dengan persamaan $\mathrm{Y}=2,2833 \mathrm{x}-0,8$ dan $\mathrm{R} 2=0,9227$. Hasil persamaan linier pertumbuhan mikroorganisme dalam waktu 24 jam dapat disimpulkan bahwa waktu maserasi memiliki hubungan yang cukup kuat terhadap pertumbuhan mikroorganisme. Persamaan regresi linier dapat digunakan untuk menentukan pendugaan dalam berapa jam jumlah mikroba pada media yang diberi ekstrak bawang putih akan sama dengan jumlah mikroba pada media kontrol (tanpa ekstrak bawang putih) Pada persamaan linier $\mathrm{Y}=19,017 \mathrm{x}-51,4$ didapatkan nilai $\mathrm{x}=27,15$ jam sehingga dapat disimpulkan bahwa jumlah total mikroba pada media yang diberi ekstrak bawang putih akan sama dengan jumlah total mikroba pada media kontrol (tanpa ekstrak bawang putih) dalam waktu 1 hari 3 jam 7 menit. Persamaan $\mathrm{Y}=2,2833 \mathrm{x}-0,8$ dan $\mathrm{R} 2=0,9277$ didapatkan nilai $\mathrm{x}=34,94$ jam sehingga dapat disimpulkan bahwa jumlah Staphylococcus aureus pada media yang diberi ekstrak bawang putih akan sama dengan jumlah Staphylococcus aureus pada media kontrol (tanpa ekstrak bawang putih) dalam waktu 1 hari 10 jam 56 menit.

Selama penyimpanan, kandungan allicin akan menurun dan sebaliknya diikuti naiknya konsentrasi senyawa-senyawa baru. Senyawa yang dominan terkandung adalah S-alil sistein dan Sallilmerkaptosistein (SAMC) (Amagase et al.,2001). 


\section{Tahap III}

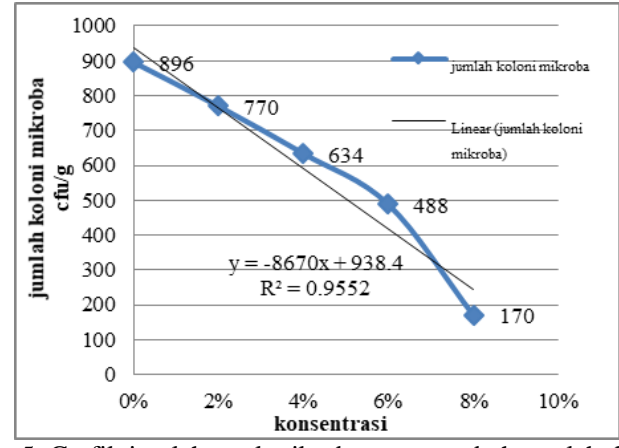

Gambar 5. Grafik jumlah total mikroba yang tumbuh setelah dihambat oleh konsentrasi ekstrak bawang putih yang berbeda-beda.

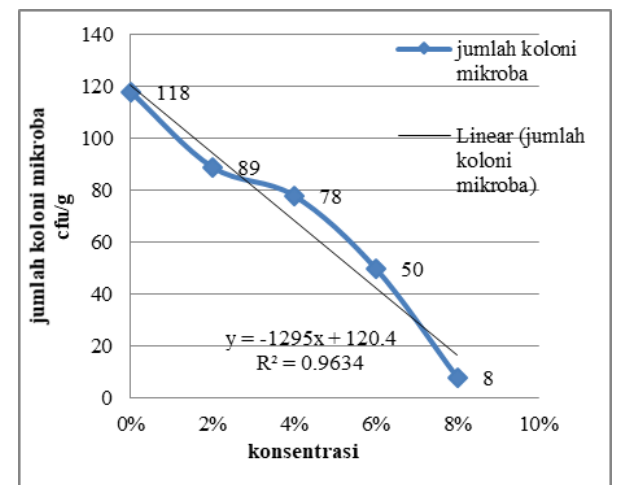

Gambar 6. Grafik jumlah koloni Staphylococcus aureus yang tumbuh setelah dihambat oleh konsentrasi ekstrak bawang putih yang berbeda-beda

Berdasarkan grafik diatas diperoleh persamaan linier $\mathrm{Y}=-8670 \mathrm{x}+938,4$ dengan $\mathrm{R} 2=0,9552$ pada grafik total koloni mikroba dan persamaan $\mathrm{Y}=-1295 \mathrm{x}+120,4$ dengan R2 = 0,9634 pada grafik jumlah Staphylococcus aureus. Hasil persamaan linier pertumbuhan mikroorganisme pada konsentrasi yang berbeda-beda dapat disimpulkan bahwa konsentrasi ekstrak bawang putih memiliki hubungan yang kuat terhadap pertumbuhan mikroorganisme dan semakin tinggi konsentrasi ekstrak bawang putih maka semakin rendah jumlah mikroorganisme.

Penurunan jumlah mikroorganisme yang tajam terjadi pada konsentrasi ekstrak bawang putih $8 \%$. Hal ini disebabkan karena semakin tinggi konsentrasi ekstrak bawang putih maka aktivitas antibakterinya akan semakin tinggi sehingga semakin rendah pertumbuhan mikroba (Nilam, 2013).

Berdasarkan hasil penelitian tahap III, pertumbuhan S.aureus dan total mikroba yang paling rendah terjadi pada konsentrasi 8\% sehingga dapat disimpulkan konsentrasi ekstrak bawang putih yang terpilih adalah $8 \%$.

\section{Tahap IV}

1. Kadar Air

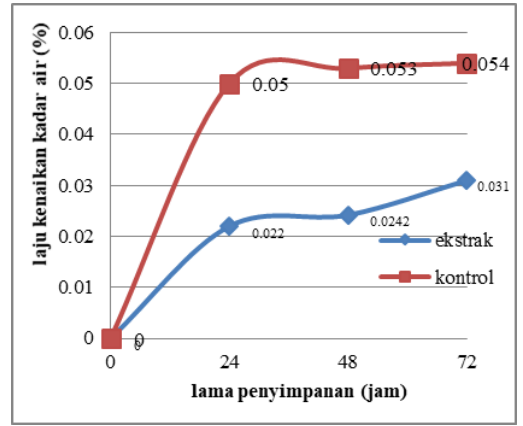

Gambar 7. Grafik laju kenaikan kadar air pada daging sapi selama penyimpanan 72 jam

Berdasarkan grafik diatas dapat disimpulkan bahwa semakin lama penyimpanan maka laju kenaikan kadar air pada daging sapi semakin meningkat. Laju kenaikan kadar air pada daging kontrol lebih tinggi dibandingkan dengan laju kenaikan kadar air pada daging yang diberi ekstrak bawang putih.

Selama penyimpanan, kadar air relatif bertambah hal ini salah satunya dikarenakan oleh penguraian mikroorganisme. Perubahan tersebut secara fisik, kimia, mikrobiologi dan organoleptik. Daging memiliki karbohidrat berupa glikogen dalam jumlah sedikit. Mikroba akan mengurai karbohidrat yang bermolekul besar seperti polisakarida menjadi glukosa (monosakarida) atau maltosa (disakarida). Monosakarida dalam proses glikolisis akan diubah menjadi asam piruvat. Asam piruvat ini selanjutnya diubah menjadi asam trikarboksilat dalam siklus Krebs dan akhirnya terpecah menjadi $\mathrm{CO} 2$ dan $\mathrm{H} 2 \mathrm{O}$, sehingga kadar air semakin meningkat (Soeparno, 2005).

2. $\mathrm{pH}$

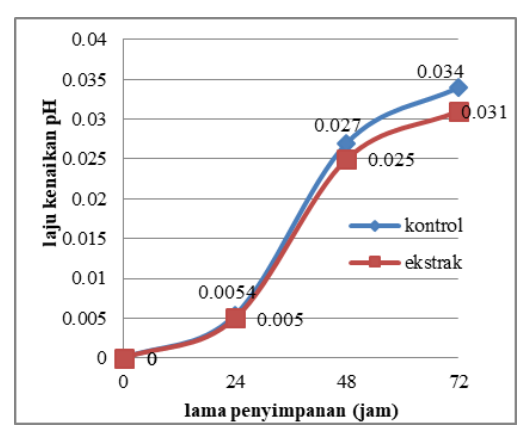

Gambar 8. Grafik laju kenaikan $\mathrm{pH}$ pada daging selama penyimpanan 72 jam

Berdasarkan grafik diatas dapat disimpulkan bahwa semakin lama penyimpanan maka laju kenaikan $\mathrm{pH}$ semakin meningkat dan $\mathrm{pH}$ daging kontrol lebih tinggi dibandingkan dengan $\mathrm{pH}$ daging yang telah diberi ekstrak. Nilai $\mathrm{pH}$ daging yang semakin tinggi disebabkan karena mikroba akan mendeaminasi asam amino dan menggunakan sisa molekulnya sebagai sumber energi sehingga jumlah $\mathrm{NH} 3$ dan $\mathrm{H} 2 \mathrm{~S}$ meningkat, dengan meningkatnya $\mathrm{NH} 3$ maka nilai $\mathrm{pH}$ juga meningkat (Rizki, 2011). 
3. Tekstur

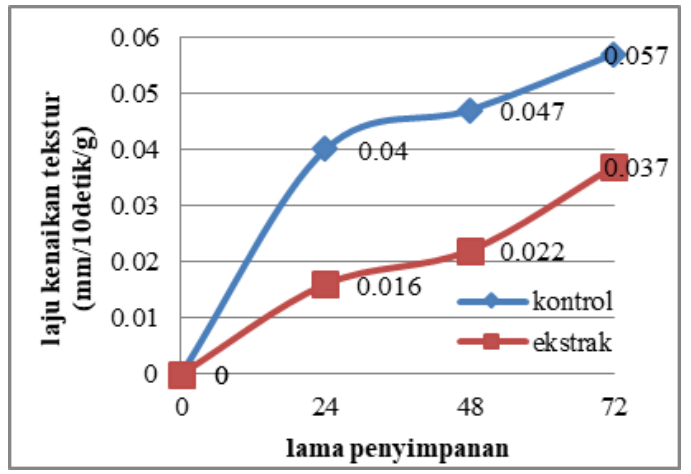

Gambar 9. Grafik laju kenaikan tekstur daging sapi selama penyimpanan $72 \mathrm{jam}$

Berdasarkan grafik diatas dapat disimpulkan bahwa semakin lama penyimpanan maka terkstur daging akan semakin tinggi. Seiring dengan lamanya penyimpanan keempukan dari daging semakin meningkat hal ini karena seiring dengan meningkatnya kadar air dari daging dan adanya kerja dari enzim katepsin yang dapat menguraikan serabut otot pada daging.

4. Total Mikroba

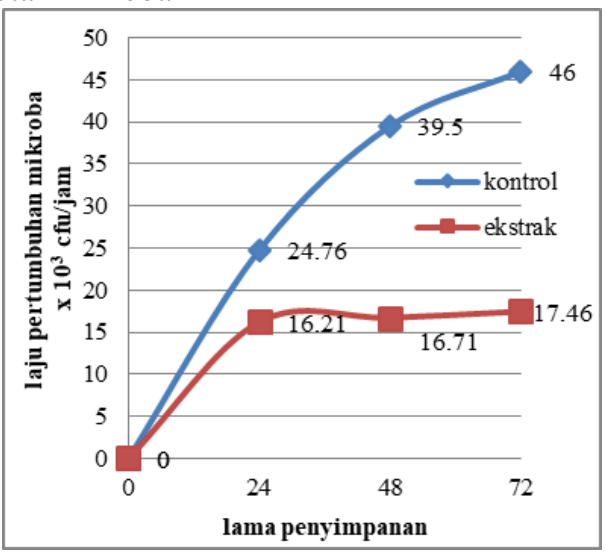

Gambar 10. Grafik laju pertumbuhan total mikroba daging sapi selama penyimpanan $72 \mathrm{jam}$

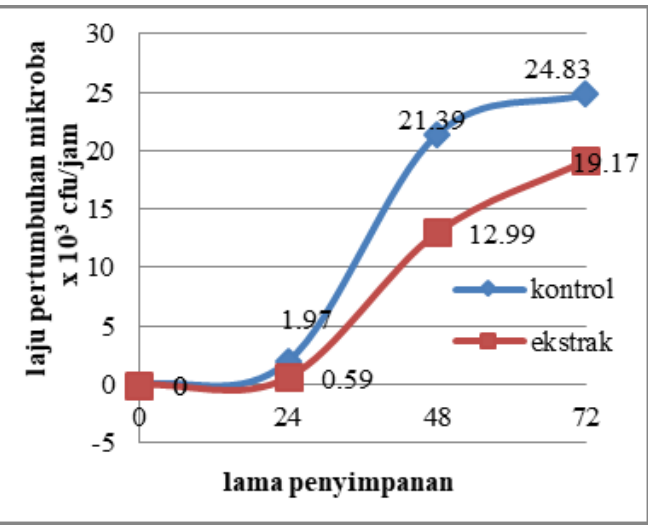

Gambar 11. Grafik laju pertumbuhan S. aureus pada daging sapi selama penyimpanan $72 \mathrm{jam}$.
Berdasarkan grafik diatas dapat disimpulkan bahwa semakin lama penyimpanan maka jumlah mikroba akan meningkat. Hal ini disebabkan karena pada saat penyimpanan dilakukan di suhu ruang $\pm 27 \mathrm{oC}$ dan dilakukan secara aerob sehingga memungkinkan terkontaminasi oleh bakteri dari udara sehingga populasi jumlah mikroba terus meningkat dan kemampuan zat antimikroba menurun.

Mutu daging salah satunya dapat dinilai dari tingkat kontaminan terhadap mikroba patogen . Kontaminasi mikroba patogen bahkan dapat dikatakan sebagai indikator yang paling penting yang menjadi acuan apakah mutu suatu daging masih baik atau sudah tidak layak dikonsumsi(karena sudah mengandung banyak mikroba patogen yang membahayakan kesehatan (Widianingrum, 2013).

Berdasarkan hasil penelitian, dapat diambil kesimpulan sebagai berikut.

1. Hasil penelitian pendahuluan menunjukkan bahwa kolagen ikan gurami mengandung kadar total Nitrogen sebesar 12,32\%, kadar Abu sebesar $0,746 \%$, pH 6,5 dan titik leleh $28^{\circ} \mathrm{C}$ yang menunjukan kolagen ikan yang dihasilkan sesuai dengan SNI. Rendemen yang dihasilkan sebesar $2,34 \%$.

2. Total mikroba dan Staphylococcus aureus dapat dihambat oleh ekstrak bawang putih dilihat dari laju pertumbuhan mikroba.

3. Hasil pengujian pada tahap I dapat diambil kesimpulan bahwa salah satu senyawa organosulfur yang bersifat antimikroba adalah diallyl disulfide dengan luas area $1,73 \%$.

4. Hasil pengujian tahap II dapat disimpulkan bahwa waktu maserasi ekstrak bawang putih terbaik dalam menghambat mikroorganisme yaitu dengan waktu maserasi selama 6 jam

5. Hasil pengujian tahap III dapat disimpulkan bahwa konsentrasi ekstrak bawang putih yang paling efektif dalam menghambat mikroorganisme yaitu pada konsentrasi $8 \%$.

6. Hasil pengujian tahap IV dapat disimpulkan bahwa semakin lama penyimpanan maka \%Air, pH, tekstur, total mikroba dan jumlah Staphylococcus aureus semakin meningkat.

\section{Daftar Pustaka}

1. Amagase, H., B.L. Petesch, H. Matsuura, S. Kasuga, dan Y. Itakura. 2001. Intake of Garlic and Its Bioactive Components. The Journal of Nutrition 131:955S-962S.

2. AOAC. 1995. Official methods of analysis of AOAC international 16th.ed. AOAC International, Arlington. Arizona.

3. Bayu. 2011. Pengaruh Perendaman Daging Sapi dalam Larutan Kelopak Bunga Rosela (Hibiscus sabdariffa Linn) terhadap nilai pH, total koloni bakteri, daya simpan dan nilai organoleptik. 
Skirpsi. Fakultas Peternakan universitas andalas. Padang.

4. Fithri RNB. 2009. Daya antibakteri ekstrak bawang putih (allium sativum) dalam menghambat pertumbuhan staphylococcus aureus dan escherichia coli pada daging sapi. (Skripsi). Bandung: Institut Teknologi Bandung.

5. Harborne. 1996. Metode Fitokimia : Penuntun Cara Modern Menganalisis Tumbuhan.Terbitan Kedua. Terjemahan : K. Padmawinata dan I. Soediro. Bandung : Penerbit ITB

6. Katria. 2006. Ekstraksi dan identifikasi komponen sulfide pada bawang putih.Universitas Negri Semarang.

7. Kementrian Pertanian RI. 2013. Sub sector holtikultura.

http://www.pertanian.go.id/ap_pages/mod/datahorti . Diakses, 7 April 2015.

8. Lingga ME \& MM Rustama. 2005. Uji Aktivitas Antibakteri dari Ekstrak Air dan Etanol Bawang Putih (Allium sativum L.) terhadap Bakteri Gram Negatif dan Gram Positif yang Diisolasi dari Udang Dogol (Metapenaeus monoceros), Udang Lobster (Panulirus sp), dan Udang Rebon (Mysis dan Acetes). Jurnal Biotika 5 (2).

9. Nilam, 2013. Uji efektivitas ekstrak bawang putih sebagai antibakteri pada ikan bandeng. Tesis. Universitas Negri Semarang. Semarang.

10. Nurwantoro. 2012. Nilai ph, kadar air, dan total Escherichia coli daging sapi yang dimarinasi dalam jus bawang putih. Jurnal aplikasi teknologi pangan. Fakultas peternakan. Universitas diponogoro. Semarang

11. Rizki. 2011. Pengaruh Konsentrasi asap cair tempurung kenari dan lama penyimpanan terhadap kualitas kimia dan fisik daging. Universitas gajah mada, Yogyakarta

12. Safithri M. 2004. Aktivitas antibakteri bawang putih (Allium sativum) terhadap bakteri mastitis subklinis secara in vitro dan in vivo pada ambing tikus putih (Rattusnovergicus) [tesis]. Bogor: Sekolah pascasarjana, Institut Pertanian Bogor.

13. Soeparno. 2005. Ilmu dan teknologi daging. Gajah Mada University. Press. Yogyakarta.

14. Suharti, S. 2004. Kajian Antibakteri Temulawak, Jahe dan Bawang Putih Terhadap Bakteri Salmonella typhimurium Serta Pengaruh Bawang Putih Terhadap Performan dan Respon Imun Ayam Pindang. Tesis. Sekolah Pascasarjana, Institut Pertanian Bogor.

15. Sumpeno Putro, (2008). Aplikasi ekstrak bawang putih untuk memperpanjang daya simpan ikan kembung segar. Jurnal pascapanen dan bioteknologi kelautan dan perikanan.vol 3

16. Widaningrum, 2013. Kajian pemanfaatan rempah-rempah sebagai pengawet alami pada daging. Seminar nasional hari pangann sedunia xxvii, Bogor.

17. Wiryawan KG, S Suharti \& M Bintang. 2005. Kajian Antibakteri Temulawak, Jahe dan Bawang Putih terhadap Salmonella typhimurium serta Pengaruh Bawang Putih terhadap Performans dan Respons Imun Ayam Pedaging. Media Peternakan 28 (2):52-62. 